\title{
Влияние социально-экономического статуса населения северо-востока России на отношение к мигрантам ${ }^{1}$
}

\author{
О.В. ВАСИЛЬЕВА*
}

\begin{abstract}
*Ольга Валерьевна Васильева - кандидат политических наук, научный сотрудник, Институт гуманитарных исследований и проблем малочисленных народов Севера СО РАН. Адрес: 677027, Якутск, ул. Петровского, д. 1. E-mail: olgaosipovaigi@gmail.com
\end{abstract}

Цитирование: Васильева О.В. (2019) Влияние социально-экономического статуса населения северо-востока России на отношение к мигрантам // Мир России. Т. 28. № 4. C. 152-171. DOI: 10.17323/1811-038X-2019-28-4-152-171

Целью настоящей статьи является определение наличия связи между субъективными оченками собственного социально-экономического статуса населения на северо-востоке России и их отношением к мигрантам. В статье рассматриваются результать социологического исследования, проведенного методом анкетирования в трех населенных пунктах Якутии с общим объемом выборки, насчитывающим 654 наблюдения. Выделены три условные группы, отличающцеся сочиально-экономическим статусом их членов: малообеспеченные, среднеобеспеченные, высокообеспеченные. Проанализированы связи между сочиальными и демографическими особенностями данных групп и отношением к мигрантам. Как показывает исследование, связь между антимигрантскими настроениями и социиально-экономическим статусом действительно существует, при этом формирование негативных представлений переплетается с наличием/отсутствием экономического, квалификационного и властного ресурсов.

Ключевые слова: мигранты, интеграция мигрантов, принимающее сообщество, социальная структура, социальная стратификация, социально-экономический статус, антимигрантские настроения, этнические группы, Якутия, межнациональные отношения, северо-восток России

\footnotetext{
1 В статье используются результаты исследования, выполненного при поддержке гранта РГНФ № 16-13-14001 «Принимающее сообщество: проблемы интеграции мигрантов в контексте формирования гражданской нации» (2016-2017 гг.).
} 
Глубокие изменения в демографических процессах выявляют ряд проблем, к которым в российском случае можно отнести недонаселенность отдельных территорий, демографическое старение населения, низкую рождаемость и высокую смертность. В аналитическом докладе «Демографические вызовы России», подготовленном Центром стратегических разработок, отмечается, что меры преодоления вызовов глобальному сообществу должны быть комплексными, затрагивающими разные сферы жизнедеятельности общества, но наиболее широкие возможности видятся в сфере миграционной политики [Демографические вызовы России 2017, с. 70].

Россия объективно нуждается в мигрантах, при этом следует подчеркнуть, что речь идет не о временной трудовой миграции, а о миграции, завершающейся предоставлением гражданства Российской Федерации. С учетом высокой значимости миграции необходимо обратить внимание на проблему интеграции приезжих в принимающее сообщество, которую зачастую рассматривают как односторонний процесс и дело самих переселяющихся. Тем не менее представляется очевидным, что необходимо акцентироваться и на принимающем сообществе, поскольку проблема слабой миграционной привлекательности складывается в том числе из-за высокого уровня антимигрантских настроений в обществе. Также в процессах интеграции многое зависит и от уровня социальной депривации мигрантов в принимающем сообществе. По мнению зарубежных коллег, отношение к мигрантам сказывается не только на размере их доходов, но и на качестве жизни [Waisman, Larsen 2016]. В этой связи возникает вопрос «Какие характеристики современного общества оказывают качественное влияние на формирование преимущественно негативного отношения к мигрантам и тем самым определяют интеграционную емкость общества?»

Чаще всего тема отношения принимающего сообщества к мигрантам рассматривается в свете культурных различий, но в данной статье мы хотели бы обратить внимание на социально-экономический контекст формирования антимигрантских настроений, в частности, нас интересовал вопрос «Как социально-экономический статус респондента сказывается на его отношении к мигрантам?»

\section{Обзор литературы}

Изначально проблема влияния социально-экономического статуса человека на формирование его взглядов рассматривалась прежде всего в рамках марксистской идеологии и теории борьбы классов. Если следовать этой методологии, то за любым этническим конфликтом всегда должны просматриваться интересы социальных классов. При увеличивающемся неравенстве и сопряженном с ним ухудшением социально-экономического положения отдельных групп населения не только снижаются интеграционные возможности общества, но происходит трансформация социальной напряженности в этническую. Существуют различные мнения о причинах этих процессов. Например, И. Валлерстайн и Э. Балибар считают, что ксенофобия - это проявление неорасизма, направленного на рабочий класс: «<..> антииммигрантский расизм максимально реализует отождествление классового положения и этнического происхождения (реальные основания которого всегда задавались межрегиональной, межнациональной или межконтинентальной 
подвижностью рабочего класса)». Исследователи заявляют, что современные потоки миграции сложились под влиянием прошлых взаимодействий стран в рамках колониальной системы, и расизм в отношении мигрантов является выражением, механизмом и последствием географического закрепления разделения труда на центр и периферию [Балибар, Валлерстайн 2004, с. 240]. В целом этот подход кажется обоснованным, учитывая, что так называемые культурные различия между мигрантами и представителями принимающего сообщества зачастую представляют собой скорее дистанцию между людьми с разным уровнем образования и профессиональной компетенции и в конечном счете с различными показателями благосостояния. В контексте этой идеи проблемы культурных противоречий между представителями принимающего сообщества и мигрантами должны концентрироваться между состоятельным местным населением и бедными приезжими, у которых разрыв в благосостоянии, образовательном и профессиональном уровне будет наиболее глубок. Представляется, что это актуально в первую очередь для европейских стран. Согласно современным европейским исследованиям, ключевыми предикторами антииммиграционных настроений являются региональное и национальное межличностное доверие, уровень образования, прямые иностранные инвестиции и политические переменные [Rustenbach 2010]. При этом негативное отношение к мигрантам зависит от того, каковы профессиональная квалификация последних и экономическая ситуация в стране их исхода. Вместе с тем, указывают ученые, высокая профессиональная квалификация нивелирует фактор происхождения [Ford 2017]. Г. Стендинг утверждает, что демонизация мигрантов становится частью популистской реакции на незащищенность нового растущего класса - прекариата. Политика принимающих государств приводит к тому, что мигранты вынуждены соглашаться на нелегальную работу и незначительные заработки без каких-либо социальных гарантий, тем самым пополняя ряды прекариата и подрывая переговорные возможности местных молодых работников [Стендинг 2014, с. 176], в бедственном положении которых принято винить мигрантов, а не ограниченную государственную политику в области трудовых ресурсов и социального обеспечения.

Отечественные ученые считают, что в Российской Федерации также происходит активное формирование прекариата [Шкаратан, Карачаровский, Гасюкова 2015; Тощзенко 2015], предполагающее обострение отношений между местными и приезжими. Россия, несмотря на вовлеченность в глобальные экономические процессы, демонстрирует некоторые национальные особенности, сложившиеся в ходе оформления этнической структуры страны. Высокая актуализированность этнических идентичностей, обусловленная национальной политикой государства, определяет значимость ряда специфических дискурсов, в которых внимание обращается не на социальное неравенство, которое предлагается не замечать вовсе, а на этнические различия [Малахов 2007]. По всей видимости, в условиях неолиберальной политики государства и экономической стагнации страны эти дискурсы призваны частично смягчить социальную напряженность за счет роста этнической. Подобные тенденции, демонстрирующие связь между снижением уровня социально-экономического благосостояния и ростом межэтнической напряженности, обозначены и в исследованиях ученых Института социологии РАН. Так, по результатам исследований Л.М. Дробижевой, россиян, считающих, что они «многое потеряли за последние 15-20 лет», и испытывающих неприязнь к представителям 
определенных национальностей, вдвое больше, чем тех, кто подобных чувств не выказывает [Дробижева 2012, с. 105]. Кроме того, Л.М. Дробижева указывает, что на характер межэтнических отношений в России также влияет качество жизни россиян: уровень образования, доходы, тип поселения [Дробижева 2013, с. 83].

По мнению М.Ф. Черныша, «негативным фактором, влияющим на установки общественного сознания, оказывается неравенство в том случае, когда его характер представляется большинству населения неоправданным, а масштабы превосходящими допустимые с точки зрения справедливости» [Черныли 2016, с. 34].

Таким образом, в современных исследованиях подчеркивается, что существует связь между социально-экономическим положением человека и формированием антимигрантских и ксенофобских взглядов. Однако их надо рассматривать в контексте политики государства, действия дискурсов и иных факторов. Помимо этого, важны не только объективно измеряемые показатели социально-экономического благополучия, но и субъективные оценки состояния и динамики материального положения. В этой связи в представленной статье внимание прежде всего будет сосредоточено на субъективных оценках, т.е. на проблеме отношения населения к мигрантам через призму социально-экономического самочувствия респондентов.

\section{Актуализация проблемы для северо-востока России}

Отличительной чертой восточных территорий России является слабая заселенность региона, хотя проекты, касающиеся регулируемого сдвига населения на север и восток, возникали и в царской России, и в советский период. В 90-е гг. $\mathrm{XX}$ в. начался обратный процесс, характеризующийся смещением населения с северо-восточных окраин в юго-западном направлении и почти полным совпадением вектора потоков внутренней и внешней миграции ${ }^{2}$ В результате этого демографический потенциал Сибири и Дальнего Востока оказался явно недостаточным для освоения расположенных здесь природных богатств и создания развитой экономической и поселенческой структуры [Вишневский, Андреев, Щербакова 2017, с. 8]. Кроме того, многолетняя динамика сокращения численности населения восточных территорий страны (в сочетании с его низкой плотностью) на фоне стремительно растущего населения стран Азии породила ряд проблем, сопряженных с возможностью удержания геополитического пространства.

Одной из наиболее малонаселенных территорий является Республика Саха (Якутия) (РС (Я)). В настоящее время плотность населения в Якутии составляет всего 0,3 чел. на кв. км, тогда как среднероссийский показатель - 8,4 чел. на кв. км. Сегодня к задачам развития человеческого капитала в Дальневосточном федеральном округе российская власть относит в том числе переселение 853,75 тыс. чел. [Концепция демографической политики Дальнего Востока на период до 2025 года 2017]. Предполагается, что именно на Дальнем Востоке на фоне непрекращающегося оттока коренного населения иностранная рабочая сила должна стать постоянным и неотъемлемым элементом экономики.

2 На Москву и Санкт-Петербург (вместе с областями) приходится 80\% иммиграционного притока [Малахов, Симон 2017, с. 22]. 
Миграция и раньше оказывала влияние на демографическое и социальноэкономическое развитие Республики Саха (Якутия). Наибольший прирост населения в Якутии наблюдался с 1959 по 1989 г.: тогда число проживающих в Якутской АССР увеличилось на $121,9 \%$; среднегодовые темпы прироста населения составили $4,1 \%$, в то время как в более ранние периоды они были значительно меньше - в 1897-1926 гг. - 0,2\%, 1926-1959 гг. - 2,1\% [Игнатьева 1999, с. 27 ]. Бурный рост населения 1959-1989 гг. был связан с реализацией экономической доктрины ускоренного промышленного освоения Якутии, возникновением алмазодобывающей промышленности на западе республики и промышленным освоением Крайнего Севера. Тогда миграция внесла значительные коррективы в этническую структуру населения (прежде всего городского): помимо русских и саха, пятую часть всех городских жителей Якутии составляли представители иных этнических общностей.

В 1990-е гг. переход к рыночной экономике и начало коренных преобразований в социально-экономической сфере в условиях гиперинфляции привели к тому, что северные и прочие надбавки к зарплате перестали стимулировать приток трудовых мигрантов, последовал значительный отток населения, который в меньшей степени, но все же продолжается и до настоящего времени, тогда же произошло постепенное выравнивание этнодемографической численности саха и русских.

В нулевые годы XXI в. была разработана «Схема комплексного развития производительных сил, транспорта и энергетики Якутии до 2020 года», в рамках которой планировалось создание Южно-Якутского угольно-гидроэнергетического кластера, основанного на масштабном освоении ресурсов Южной Якутии, а также на развитии транспортной и электросетевой инфраструктуры этого региона [Схема комплексного развития производительных сил, транспорта и энергетики Якутии до 2020 года, 2006, с. 143 ]. Усилия власти были направлены и на создание в регионе территорий опережающего социально-экономического развития (ТОСЭР). По сути, был объявлен новый виток индустриализации, вновь потребовавший привлечения большого количества рабочей силы. Однако в ходе реализации проектов региональные власти столкнулись с рядом проблем. В 2014 г. глава РС (Я) Е.А. Борисов заявил: «Когда мы начали заниматься освоением территории в рамках наших крупных проектов, то сразу ощутили, что не хватает рабочей силы. В свое время были установлены лимиты с нашей стороны - до 40 тыс. чел. в год. Когда массово стали привлекаться рабочие силы из Средней Азии, начались проблемы. Эти люди не знают культуры, языков, традиций наших народов - и в результате наступают определенные противоречия. Они доходят порой до криминальных разборок. Мы стали сокращать лимит. Сейчас в год приезжает 8 тыс. чел. Этого мало» [Галкина 2014].

Поиск факторов, оказывающих неблагоприятное влияние на привлечение и удержание населения на Дальнем Востоке, представляется весьма актуальной задачей. В связи с этим мы хотели бы обратить внимание на проблему интеграционной емкости принимающего сообщества современной Якутии в социально-экономическом контексте. В постсоветский период произошли серьезные перемены как в экономической, так и в социальной жизни россиян; качественно изменились социальная структура и социальный статус большинства его членов. Можно предположить, что именно эти изменения оказывают влияние на отношение принимающего сообщества к мигрантам. 


\section{Дизайн исследования}

Цель настоящей статьи состоит в том, чтобы определить наличие связи между субъективными оценками собственного социально-экономического статуса респондентов и отношением к мигрантам на северо-востоке России. Гипотеза исследования была построена на идее И. Валлерстайна и Э. Балибара о том, что антимигрантские настроения прежде всего максимально реализуют отождествление этнического происхождения и социально-экономического положения. В связи с этим следует, во-первых, определить наличие связей между социально-экономическим статусом и а) отношением к мигрантам и миграции; б) отношением к этническим общностям, представители которых наполняют миграционные потоки в Якутию. Во-вторых, необходимо выявить социальные и демографические особенности групп с разным социально-экономическим статусом и обозначить связи между ними и отношением к мигрантам.

Географическими точками исследования стали населенные пункты, в которых процессы иммиграции и изменения этнической структуры общества представляются наиболее заметными:

- Якутск - административный центр Якутии, в черте которого планируется строительства ТОСЭР «Индустриальный парк “Кангалассы”»;

- п. Нижний Бестях - наиболее привлекательный для мигрантов сельский населенный пункт;

- Нерюнгри - город-участник инвестиционного проекта «Комплексное развитие Южной Якутии».

Исследование, для реализации которого был сформирован специальный вопросник, проведено методом анкетного опроса населения в возрасте 18 лет и старше. Общий объем выборки респондентов насчитывает 654 наблюдения (Якутск - 300 респондентов, Нижний Бестях - 104, Нерюнгри - 250); половозрастные характеристики соответствуют генеральной совокупности. Гендерные показатели распределяются следующим образом: 46,5\% опрошенных - мужчины, 53,5\% - женщины. Возрастные характеристики: 18-22 года - 12,7\%, $23-34$ года - 28,6\%, 35-44 года - 18,8\%, 45-54 года - 19,3\%, 55-64 года - 13,5\%, старше 65 лет $-7,2 \%$.

Так как фокус исследования был направлен на социально-экономический контекст формирования того или иного отношения к мигрантам, необходимо было выявить некие координаты, определяющие статус человека в иерархически организованном социальном пространстве. Данная система координат вертикально ранжированного социального пространства была построена на основе самооценки респондентами собственного социально-экономического статуса. Он измерялся как субъективная оценка при ответе на вопрос «Укажите, пожалуйста, к какому социальному слою населения Вы себя относите? Выберите один ответ», на который были предложены следующие варианты ответов: 1 - «Не можем обеспечить себя питанием, одеждой и жильем», 2 - «Живем от зарплаты до зарплаты. Иногда приходится занимать», 3 - «В основном денег хватает, но при покупке товаров длительного пользования (крупная бытовая техника, мебель, зимняя одежда) наших сбережений не всегда достаточно, приходится копить), 4 - «Покупка товаров длительного пользования не вызывает у нас особых затруднений, однако 
денег на покупку квартиры, автомашины не хватает», 5 - «Мы можем позволить себе любые дорогостоящие покупки, ни в чем себе не отказываем».

С помощью процедуры перекодировки крайние позиции «1»-«2»и «4»-«5» объединялись попарно. В итоге варианты ответов были сведены к трем значениям: оценки от «1» до «2»- это «людей, оценивающих свое социально-экономическое положение ниже среднего», оценка «3» осталась неизменной и охватывала «людей, оценивших свое социально-экономическое положение как среднее», оценки от «4» до «5»- «люди, оценившие свое социально-экономическое положение выше среднего». Таким образом, на основе оценок были образованы три условные группы, отличающиеся социально-экономическим статусом их членов: «1» - малообеспеченные (26,7\% респондентов); «2»- среднеобеспеченные $(46,3 \%)$; «3» высокообеспеченные $(27 \%)$.

\section{Отношение к мигрантам в зеркале общественного мнения}

Прежде чем описывать выявленные связи между социально-экономическим статусом респондентов и их отношением к мигрантам, представим итоги исследования, касающиеся общих тенденций в отношениях к мигрантам и миграции. Как в Республике Саха (Якутия), так и в России в целом изоляционистские настроения достаточно актуализированы. На вопрос о том, нуждается ли РС (Я) в трудовых мигрантах, были получены следующие ответы: 24,6\% респондентов дали утвердительный ответ, 50,9\% - отрицательный ответ, 24,5\% затруднились ответить. Таким образом, выявлено, что к идее притока трудовых мигрантов положительно относится лишь четверть населения, проживающего в населенных пунктах опроса и наиболее активного миграционного потока.

При построении комбинационной таблицы выяснилось, что респонденты из выделенных в исследовании групп населения по-разному относятся к вопросу о том, нуждается ли республика в трудовых мигрантах. Так, респонденты из группы высокообеспеченных чаще давали положительный ответ $(36,8 \%)$ о необходимости мигрантов, нежели респонденты из групп малообеспеченных (18,3\%) и среднеобеспеченных $(21,6 \%)$, причем разброс процентов в негативных ответах не выявлен. Таким образом, в группах среднеобеспеченных и малообеспеченных респондентов выявлена тенденция к росту выбора варианта «затрудняюсь ответить».

В ходе исследования было установлено, что субъективная оценка социально-экономического статуса оказывает влияние и на то, как человек относится к мигрантам. На вопросы о том, как «Вы относитесь к мигрантам из дальнего, ближнего зарубежья, а также к приезжим из регионов России», респонденты, оценивающие свое материальное положение выше среднего, реже давали негативные варианты ответов «с раздражением и неприязнью» или «с недоверием и страхом» (таблица 1).

Стоит отметить, что с 2000 по 2014 г. в Республике Саха (Якутия) количество мигрантов, формирующих региональные трудовые ресурсы, увеличилось в 8 раз - с 3 тыс. чел. до 23,8 тыс. чел. [Мостахова 2016, с. 76]. Ими стали преимущественно приезжие из ближнего зарубежья - Армении, Таджикистана, Киргизии и Узбекистана. В связи с этим мы решили проверить гипотезу о неравноцен- 
ном восприятии различными социально-экономическими группами численности уже прибывших мигрантов, поскольку миграция - это явление, более заметное для противников, нежели для сторонников этого процесса. Таблица 2 демонстрирует, что люди с низкой и средней оценкой собственного статуса чаще давали ответ, что мигрантов много, также чаще затруднялись ответить.

Таблица 1. Отношение респондентов к мигрантам, \%

\begin{tabular}{|c|c|c|c|c|c|c|}
\hline Групша & Позитивно & Спокойно & $\begin{array}{c}\text { С раздражением, } \\
\text { неприязнью }\end{array}$ & $\begin{array}{l}\text { С недоверием, } \\
\text { страхом }\end{array}$ & $\begin{array}{c}\text { Затрудняюсь } \\
\text { ответить }\end{array}$ & Всего \\
\hline & \multicolumn{6}{|c|}{ Как вы относитесь к приезжим из дальнего зарубежья } \\
\hline 1 & 7,7 & 45,2 & 11,9 & 7,2 & 28,0 & 100,0 \\
\hline 2 & 12,4 & 55,3 & 9,3 & 6,5 & 16,5 & 100,0 \\
\hline \multirow[t]{2}{*}{3} & 20,1 & 58,6 & 7,7 & 2,4 & 11,2 & 100,0 \\
\hline & \multicolumn{6}{|c|}{ Как вы относитесь к приезжим из ближнего зарубежья } \\
\hline 1 & 9,5 & 43,5 & 18,5 & 8,3 & 20,2 & 100,0 \\
\hline 2 & 12,0 & 56,2 & 16,4 & 6,8 & 8,6 & 100,0 \\
\hline 3 & 16,0 & 64,5 & 10,0 & 3,0 & 6,5 & 100,0 \\
\hline & \multicolumn{6}{|c|}{ Как вы относитесь к мигрантам из других регионов России } \\
\hline 1 & 17,1 & 64,7 & 4,1 & 1,7 & 12,4 & 100,0 \\
\hline 2 & 23,0 & 67,7 & 4,1 & 0,7 & 4,5 & 100,0 \\
\hline 3 & 23,4 & 71,3 & 1,8 & 0,6 & 2,9 & 100,0 \\
\hline
\end{tabular}

Таблица 2. Представления населения о том, как много мигрантов проживает в населенном пункте их проживания, \%

\begin{tabular}{|l|c|c|c|c|c|c|c|}
\hline Группа & $\begin{array}{c}\text { Очень } \\
\text { много }\end{array}$ & Много & Мало & $\begin{array}{c}\text { Совсем } \\
\text { мало }\end{array}$ & Нет & $\begin{array}{c}\text { Затрудняюсь } \\
\text { ответить }\end{array}$ & Всего \\
\hline 1 & 14,2 & 36,1 & 18,9 & 6,5 & 7,7 & 16,6 & 100,0 \\
\hline 2 & 12,4 & 40,5 & 22,0 & 4,5 & 4,1 & 16,5 & 100,0 \\
\hline 3 & 7,2 & 38,7 & 32,7 & 9,5 & 3,0 & 8,9 & 100,0 \\
\hline
\end{tabular}


Анализ образовательного уровня мигрантов в трудоспособном возрасте свидетельствует, что в республику чаще приезжают работники низкой квалификации, причем среди прибывших около трети вообще не имеют специальной профессиональной подготовки. Ответы на вопрос «В каких работниках из числа трудовых мигрантов нуждается республика?»³ показали: в целом респонденты считают, что прежде всего необходимы низкоквалифицированные рабочие $(45,3 \%$ респондентов), 23,9\% опрошенных отметили, что нужны служащие, $17,7 \%$ - специалисты, $7 \%$ - руководители. Респонденты из групп мало- и среднеобеспеченных выбирали ответ «рабочие» (53 и 50\% соответственно). В свою очередь респонденты из группы высокообеспеченных отвечали подобным образом лишь в $35 \%$ случаев; значительно чаще они заявляли о необходимости для республики квалифицированных кадров - специалистов и служащих.

Неоднородность мигрантов по уровню образования, квалификации и материальному достатку становится причиной дифференциального отношения к приезжим представителей принимающей стороны. Исходя из этого, складываются и представления о том, где проходят социальные границы взаимодействия с трудовыми мигрантами. На вопрос о том, «в каких качествах Вы можете принять мигранта из ближнего зарубежья», в группе с низкими доходами лишь $22,4 \%$ респондентов рассматривали мигранта как коллегу по работе, в группе со средними доходами $-34,8 \%$, в группе с высокими доходами $-47,7 \%$; воспринимать мигранта как друга согласны были 15,9\% респондентов из группы «1», 25,9\% - из группы «2» и $35,5 \%$ - из группы «3». Что касается семейных отношений, то рассматривать приезжих из ближнего зарубежья как супруга или иного члена семьи согласны $8,2 \%$ из группы «1», $11,6 \%$ - из группы «2», $16,9 \%$ - из группы «3». Таким образом, как бы ни сужались социальные границы взаимодействия, люди, оценивающие свое материальное положение как неблагоприятное, существенно чаще настроены отрицательно.

\section{Межнациональные отношения в контексте миграции}

Распределение мигрантов, приехавших в республику из зарубежных стран на длительный срок (от 9 месяцев) в 2017 г., показывает, что абсолютное большинство прибыло из стран ближнего зарубежья: из Киргизии (40\%), Украины $(17,85 \%)$, Таджикистана (13,7\%), Армении (12,7\%) [Международная миграция 2017]. И хотя их доля в общем числе населения республики невелика, изменения и в этносоциальной структуре отдельных поселений, и в отношении к приезжим со стороны местного населения с каждым днем становятся вполне очевидными.

В связи с этим рассмотрим влияние социально-экономического положения респондентов на оценку отношения к приезжим с Кавказа и из Средней Азии. Выяснилось, что в группе с низким социально-экономическим статусом $37 \%$ респондентов заявили о своем негативном отношении к приезжим с Кавказа. В отношении мигрантов из Средней Азии $35 \%$ малообеспеченных дали негативный ответ,.

\footnotetext{
3 Предложены следующие ответы: 1) «руководители высшего и среднего звена»; 2) «специалисты с высшим образованием»; 3) «служащие и технический персонал без высшего образования»; 4) «рабочие».
} 
В группе высокообеспеченных о негативном отношении к выходцам с Кавказа заявили 18,6\% населения, в отношении приезжих из Средней Азии - 15,3\%. Группа со средним социально-экономическим положением заняла промежуточное положение (28 и 23,8\% соответственно).

Также следует затронуть проблему оценки обществом межэтнических отношений. Респондентам было предложено оценить их на уровне собственного трудового коллектива, населенного пункта проживания, а также более абстрактных для него величин: на уровне региона (Республика Саха (Якутия)) и уровне государства. Измерение производилось при помощи вопроса «Как Вы оцениваете состояние межнациональных отношений в Вашем (городе/селе)?». Предложены были следующие варианты ответов: 1 - «благоприятные», 2 - «стабильные», 3 - «напряженные», 4 - «критические», 5 - «затрудняюсь ответить». Выяснилось, что оценка состояния межнациональных отношений в месте проживания свидетельствует о достаточно благополучной ситуации: $22,6 \%$ респондентов оценили ситуацию как благоприятную, 62,1\% - как стабильную, 9,3\% - как напряженную и $0,9 \%$ - как критическую, 5,1\% затруднились ответить.

Далее были построены таблицы сопряженности, показывающие распределение ответов с оценкой состояния межнациональных отношений в населенном пункте проживания в соответствии с числом выделенных социальных слоев, а также проведен тест $\mathrm{x}^{2}$. Сформированы нулевая и альтернативная гипотезы и задан уровень значимости 0,05. Нулевая гипотеза сводилась к тому, что респонденты различных социальных слоев оценивают межнациональные отношения по выделенным типам одинаково. Альтернативная гипотеза предполагала, что состояние межнациональных отношений респонденты будут оценивать по-разному. В результате была подтверждена альтернативная гипотеза: эмпирическое значение для теста $\mathrm{x}^{2}$ составило 29,748, уровень значимости - 0,000. Таким образом, было установлено, что для уровня населенного пункта существует значимая связь между тем, к какому социальному слою относит себя респондент и как он оценивает состояние межнациональных отношений в населенном пункте (таблица 3). Оказалось, что, чем более неблагоприятно респондентами оценивается собственное социально-экономическое положение, тем с большей вероятностью они рассматривают межнациональные отношения в своем населенном пункте как конфликтные или напряженные.

Таблица 3. «Оцените состояние межнациональных отношений в вашем населенном пункте», \%

\begin{tabular}{|l|c|c|c|c|c|c|}
\hline Группа & Благоприятное & Стабильное & Напряженное & Критическое & $\begin{array}{c}\text { Затрудняюсь } \\
\text { ответить }\end{array}$ & Всего \\
\hline 1 & 18,5 & 56,5 & 13,1 & 2,4 & 9,5 & 100,0 \\
\hline 2 & 20,6 & 67,7 & 8,2 & 0,7 & 2,7 & 100,0 \\
\hline 3 & 30,2 & 59,3 & 7,6 & & 2,9 & 100,0 \\
\hline Всего & $\mathbf{2 2 , 7}$ & $\mathbf{6 2 , 4}$ & $\mathbf{9 , 4}$ & $\mathbf{1 , 0}$ & $\mathbf{4 , 6}$ & \\
\hline
\end{tabular}


Далее была проанализирована гипотеза, согласно которой те, кто не удовлетворен своим материальным положением, с большей вероятностью склонны оценивать межнациональные отношения на уровне Российской Федерации как напряженные или конфликтные, чем те, кто находится в более благоприятной экономической ситуации и оценивает свое положение более позитивно. Рассмотрим простые частоты по данному вопросу: благоприятно оценили состояние межнациональных отношений в России 9,0\% респондентов, как стабильное $-47,6 \%$, $25,6 \%$ высказали мнение, что межнациональные отношения в России напряженные, $6,2 \%$ оценили их состояние как критическое, $11,6 \%$ затруднились ответить. Можно заметить, что состояние межнациональных отношений в России в целом оценивается опрошенными существенно хуже, что подтвердило вышеуказанную гипотезу (таблица 4).

Таблица 4. «Оцените состояние межнациональных отношений в России», \%

\begin{tabular}{|l|c|c|c|c|c|c|}
\hline Группа & Благоприятное & Стабильное & Напряженное & Критическое & $\begin{array}{c}\text { Затрудняюсь } \\
\text { ответить }\end{array}$ & Всего \\
\hline 1 & 6,5 & 42,3 & 27,4 & 6,0 & 17,9 & 100,0 \\
\hline 2 & 8,9 & 44,9 & 28,8 & 5,1 & 12,3 & 100,0 \\
\hline 3 & 11,8 & 57,6 & 18,2 & 8,2 & 4,1 & 100,0 \\
\hline Всего & $\mathbf{9 , 0}$ & $\mathbf{4 7 , 6}$ & $\mathbf{2 5 , 6}$ & $\mathbf{6 , 2}$ & $\mathbf{1 1 , 6}$ & \\
\hline
\end{tabular}

Однако стоит обратить внимание на то, что на более абстрактном для опрашиваемых уровне Российской Федерации число респондентов, оценивающих состояние межэтнических отношений как напряженное, повышается в первую очередь за счет респондентов, причисливших себя к социальному слою со средними доходами.

\section{Особенности выделенных групп с различным социально-экономическим статусом}

Таким образом, на основе данных можно сделать вывод о более негативном отношении к мигрантам респондентов с низкими социально-экономическим статусом. Возникает вопрос, какими же характеристиками обладают представители указанных выше групп, помимо особенностей оценки уровня благосостояния?

Для определения специфики социальных профилей были построены таблицы сопряжения и рассчитаны статистики $\chi^{2}$ по категориям возраста, пола, образования. Уровень значимости критерия $\chi^{2}$ показал, что статистически связанными с социально-экономическим самоопределением оказываются возраст и образование респондента, тип поселения, при этом гендерные характеристики не актуализированы (таблица 5). 
Таблица 5. Оценка влияния объективных факторов на особенности групп

\begin{tabular}{|l|c|c|c|}
\hline Признак & Критерий $\chi^{2}$ Пирсона & $\begin{array}{c}\text { Степени } \\
\text { свободы }\end{array}$ & $\begin{array}{c}\text { Асимптотическая } \\
\text { значимость }\end{array}$ \\
\hline Возраст & 14,183 & 10 & 0,165 \\
\hline Пол & 0,084 & 2 & 0,959 \\
\hline Образование & 60,623 & 8 & 0,000 \\
\hline Тип поселения & 3,442 & 2 & 0,179 \\
\hline
\end{tabular}

Повышение возраста наблюдается при переходе от группы «1» к группе «3» группе и характеризуется усилением толерантности по отношению к мигрантам. Указанную тенденцию исследователи склонны объяснять тем, что представители старших поколений, часть жизни прожившие в условиях советского общества и ностальгирующие по интернациональному обществу и дружбе народов, не склонны считать национальные различия серьезной угрозой, так как их личный жизненный опыт имел практику мирного сосуществования и дружеских отношений с людьми других национальностей [Межэтническая напряженность в меняющемся социальном контексте 2017, с. 35].

Вторым фактором, разделяющим группы, становится образование, которое, по данным европейских исследований, оказывается связанным с отношением к мигрантам (чем оно выше, тем терпимее респондент) [Rustenbach 2010]. Согласно межстрановому анализу В.А. Проходы, в России, в отличие от стран Европы, не фиксируется значимая прямая корреляция между уровнем образования респондентов и их отношением к мигрантам. По мнению исследователя, причина этого кроется в том, что национальная система образования не производит в достаточной степени социокультурные образцы поведения, способствующие формированию толерантного отношения к мигрантам [Прохода 2018, с. 334]. Другое объяснение этому обстоятельству предлагает О.И. Шкаратан, считающий, что в России образование как составляющая человеческого капитала может совмещаться как с высоким, так и с низким доходом, т.е. связь между двумя категориями неоднозначна, хотя определено, что в развитых странах чем значительнее человеческий капитал, тем более высокими доходами обладает его носитель [Шкаратан 2008, с. 65].

Итак, как было указано выше, социально-экономический статус связан с уровнем образования респондента. Для того чтобы определить наличие связи между категориями «уровень образования» и «отношение к мигрантам», в срезе категории «социально-экономические группы» был применен тест $\mathrm{x}^{2}$. Он показал, что в группах «1» и «2» люди с разным уровнем образования в целом относятся к мигрантам одинаково. Значимая связь была выявлена лишь в группе «3» в ответах на вопрос об отношении к мигрантам из ближнего и дальнего зарубежья. Опрос показал, что респонденты из группы высокообеспеченных с разным уровнем образования относятся к мигрантам по-разному: так, высокая оценка собственного материального положения, сочетающаяся с высоким уровнем образования, как правило, делает людей более позитивно настроенными относительно мигрантов. 
Для объяснения этого момента можно привести доводы Н.Е. Тихоновой, которая выявила, что представители разных слоев общества заметно различаются отношением к качеству своего человеческого капитала и к его поддержанию и наращиванию. Представители высокообеспеченных слоев выделяются здесь включенностью в процесс непрерывного образования [Тихонова 2014, с. 147]. Таким образом, благополучие социально-экономического положения дает возможность для повышения качества своего человеческого капитала, что сказывается на отношении к приезжим.

Тип поселения также оказывает влияние на формирование социально-экономических групп: в категории «поселок» значительно меньшее количество респондентов отнесли себя к высокообеспеченным; здесь шире представлена группа среднеобеспеченных; число малообеспеченных в целом совпадало как в городе, так и в сельском населенном пункте.

Таблица 6. Оценка влияния субъвекивных факторов на особенности групп

\begin{tabular}{|c|c|c|c|c|}
\hline Признак & Критерий $\chi^{2}$ Пирсона & $\begin{array}{l}\text { Степени } \\
\text { свободы }\end{array}$ & $\begin{array}{c}\text { Асимптотическая } \\
\text { значимость }\end{array}$ & $\begin{array}{c}\text { Коэффициент } \\
\Phi_{и}\end{array}$ \\
\hline Удовлетворенность работой & 52,779 & 8 &, 000 & ,309 \\
\hline $\begin{array}{l}\text { Удовлетворенность } \\
\text { социальной сферой }\end{array}$ & 11,456 & 4 & 020 & ,134 \\
\hline $\begin{array}{l}\text { Удовлетворенность } \\
\text { жилищными условиями }\end{array}$ & 62,476 & 6 &, 000 & ,314 \\
\hline Уверенность в будущем & 51,032 & 8 & 000 & ,284 \\
\hline $\begin{array}{l}\text { Можете ли вы повлиять } \\
\text { на принятие общественно } \\
\text { значимых решений } \\
\text { в вашем населенном пункте }\end{array}$ & 38,376 & 4 &, 000 & ,247 \\
\hline $\begin{array}{l}\text { Считаете ли вы } \\
\text { справедливой современную } \\
\text { социально-экономическую } \\
\text { структуру общества }\end{array}$ & 28,949 & 8 &, 000 & ,214 \\
\hline
\end{tabular}

Помимо этого, были определены иные особенности выделенных групп ( $m a$ блица б). Было установлено, что респонденты из разных социально-экономических групп имеют различные представления об удовлетворенности жизнью. Теснота связи, вычисленная при помощи коэффициента Фи, между двумя переменными оказалась не столь высокой. Тем не менее следует указать, что низкие доходы ассоциируются у опрошенных с общей неудовлетворенностью жизнью и отсутствием уверенности в будущем. Особое внимание необходимо обратить и на меру социальной власти - властный ресурс, которым располагают представители разных групп. Данный индикатор был рассчитан на основе вопроса о возможности 
оказать какое-либо влияние на принятие общественно значимых решений в населенном пункте проживания ${ }^{4}$.

Респонденты из высокообеспеченной группы чаще заявляют о том, что считают современную социально-экономическую структуру общества России справедливой. В свою очередь в группах среднеобеспеченных и малообеспеченных наблюдается тенденция к сокращению частоты выбора данного варианта ответа. Наиболее часто отрицательный ответ был получен в группе малообеспеченных респондентов По всей видимости, респонденты из группы высокообеспеченных лучше адаптированы к текущим социально-экономическим условиям, среди тех, кто причислил себя к малообеспеченным слоям населения, больше тех, кто не может адаптироваться и считает нынешнюю ситуацию несправедливой ( таблица б).

\section{Размышления}

Результаты исследования при их сравнении с другими аналогичными аналитическими работами требуют некоторых пояснений. Изначально мы полагали, что основная линия раздела будет проходить между местными и приезжими, там, где социально-экономические и этнокультурные границы накладываются друг на друга, и, следовательно, мигранты будут восприниматься как представители низшего класса. Однако выяснилось, что негативное отношение к мигрантам испытывают именно представители наиболее малообеспеченных слоев населения, характеризующиеся и более низким уровнем образования, и отсутствием властного ресурса. Для работы над интерпретацией полученных результатов мы обратились к исследованиям социальной структуры российского общества. Важные пояснения, на наш взгляд, содержит ресурсный подход, разрабатываемый Н.Е. Тихоновой [Тихонова 2014], согласно которому значительная часть российского общества обладает низкими социальными, властными и квалификационными ресурсами, что уравнивает их положение с мигрантами. Подтверждение этому мы находим и в рамках нашего исследования, демонстрирующего, что приезжие, предлагая демпинговые цены за свой труд, претендуют в основном на занятость в сегменте, в котором трудятся малообеспеченные слои россиян. В результате этого возникает конкурентная ситуация за ограниченные ресурсы, формирующая негативное отношение к мигрантам и провоцирующая этнические конфликты.

Негативную роль играет и политика на рынке труда, которую проводят крупные российские корпорации, участвующие в промышленном освоении Якутии. Например, корпорация «Мечел» после приобретения компании «Якутуголь» провела массовые сокращения работников, что создало напряженную ситуацию в Нерюнгри, где основная масса трудоспособного населения была занята в угольной компании. Также нерюнгринцы рассчитывали, что будут заняты на строительстве нефтепровода «Восточная Сибирь - Тихий океан», «однако их надежды не оправдались, т.к. компания “Транснефть” привлекла к строительству нефтепровода около 800 китайских рабочих фирмы СРР» [Егоров 2015, с. 73].

4 Группа малообеспеченных объединила тех, кто этого ресурса был лишен. 
В условиях глобального отказа от решения проблемы устойчивой занятости и «незащищенного труда» негарантированная занятость обретает внушительные масштабы [Тощенко 2018, с. 65]. По всей видимости, россияне с низким социально-экономическим статусом уже сейчас вовлечены в такие трудовые отношения, которые не только не позволяют им оценить свое материальное состояние как благополучное, но и провоцируют чувство неудовлетворенности и неуверенности. Индивидуализация жизненных планов и стратегий возлагает ответственность за отсутствие восходящей вертикальной мобильности на плечи малообеспеченных, хотя на самом деле активность по повышению своего статуса может протекать в очень узком коридоре возможностей, где решающую роль играют структурные ограничения. Ощущая свою незащищенность, они чаще выражают негативное отношение к мигрантам и ко всем иным. Таким образом, результаты исследования, приведенные в статье, пересекаются с данными о формировании нового класса прекариата, прежде всего, характеризующегося своей неустойчивой занятостью.

Еще одно обстоятельство, которое необходимо учитывать, заключается в особенности социально-экономических групп. В рамках ресурсного подхода Н.Е. Тихонова показывает, что низкие доходы в России ассоциированы с низким уровнем человеческого и культурного капитала. Освоение определенного типа культуры в процессе социализации прямо влияет не только на собственный уровень образования и квалификации человека, но и на мобильность его психики, тип локус-контроля, а также на его включенность в процесс непрерывного образования [Тихонова 2014, с. 88]. Исходя из этого формируются жизненные установки и определенные поведенческие модели, в том числе и отношение к иноэтническим общностям.

Заметную роль в сложившейся ситуации может играть и подверженность медийным манипуляциям, когда дискурс этнизации миграции также оказывается значимым фактором формирования межэтнической напряженности, и в первую очередь в отношении той части населения, которая находится на негативном полюсе социально-экономического поля и уже вовлечена в отношения неравенства в качестве ущемленной категории населения. Однако доля респондентов, готовых солидаризироваться с крайними антимигрантскими высказываниями, сильно колеблется в зависимости от того, какую линию избрали в тот или иной момент центральные телеканалы [Малахов, Симон 2017, с. 20].

Европейские исследования в этой области являются весьма значимым фактором для интерпретации данных, касающихся отношения к мигрантам высокообеспеченных слоев населения. По всей видимости, респонденты из групп «3», заявляя о возможности дружбы и родственных отношений с мигрантами, имеют в виду людей с более высоким уровнем квалификации и благосостояния. Таким образом, замечание Р. Форда о том, что квалификация нивелирует фактор происхождения при формировании отношения к мигрантам, можно считать применимым и к отечественным реалиям [Ford 2017].

Идея М.Ф. Черныша о том, что неравенство оказывает особенно негативное влияние на формирование социальной напряженности, когда его характер представляется большинству населения несправедливым, тоже находит подтверждение в рамках проведенного нами анализа [Черныш 2016]. Действительно, люди с низким социально-экономическим статусом чаще оценивают текущую социальную структуру общества как несправедливую, что комбинируется с их неудовлетворенностью качеством жизни и негативным отношением к мигрантам. 


\section{Заключение}

Социологическое исследование доказывает наличие связи между оценкой респондентов своего социально-экономического статуса и их отношением к миграции и мигрантам; обнаружена связь и с тем, как воспринимаются межэтнические отношения.

Полученный результат позволяет в краткосрочной перспективе прогнозировать спокойную ситуацию в Якутии с малой вероятностью всплесков межэтнической напряженности благодаря в целом благоприятному климату в сфере межэтнических отношений. Однако для оценки ситуации в долгосрочной перспективе с учетом утвержденной Концепции демографической политики следует обратить внимание на существование связи между субъективной оценкой социально-экономического положения и оценкой состояния межэтнических отношений и отношения респондентов к мигрантам. Анализ показал, что негативное отношение к мигрантам и ксенофобские настроения имеют свои корни в социальной структуре общества, где значительная часть населения характеризуется отсутствием экономического, властного и квалификационного ресурса. Исходя из этого, можно предположить, что люди с низким уровнями доходов и образования (чаще всего молодежь) могут быть вовлечены в искусственно создаваемые ситуации межэтнических конфликтов. В настоящее время агрессия исключенной молодежи может уходить в бессмысленные проявления вандализма и хулиганства, однако в случае возможных этноконфликтных ситуаций она может быть использована различными силами, заинтересованными в нагнетании напряжения, в русло этнической мобилизации. Высокая актуализация этничности, особенно саха, фиксируемая исследователями [Осипова 2016], восприятие нынешней ситуации в сфере межнациональных отношений как напряженной, неудовлетворенность социально-экономической структурой, воспринимаемой как несправедливость, способны привести к эскалации мелких бытовых конфликтов между людьми разных национальностей вплоть до массового конфликта.

\section{Литература}

Балибар Э., Валлерстайн И. (2004) Раса, нация, класс. Двусмысленные идентичности. М.: Логос.

Вишневский А.Г., Андреев Е.М., Щербакова Е.М. (2017) Демографические вызовы России. Часть первая - население и пространство // ДемоскопWeekly. № 749-750 // http://demoscope.ru/weekly/2017/0749/tema01.php

Галкина М. (2014) «Мы предлагаем не ограничиваться Китаем» // EastRussia.ru. 17 июня 2014 // https://www.eastrussia.ru/material/my_predlagaem_ne_ogranichivatsya_kitaem/

Демографические вызовы России. ский доклад (2017) // Центр стратегических разработок // https://www.csr.ru/wp-content/uploads/2017/11/Report-Demography-web.pdf

Дробижева Л.М. (2012) Ресурс межнационального согласия и баланс нетерпимости в современном российском обществе // Мир России. № 4. С. 91-110.

Дробижева Л.М. (2013) Исчезает ли этничность в городской среде? Некоторые ответы на загадки большого города // Известия высших учебных заведений. Приволжский регион. Общественные науки. №3(27). С. 73-83. 
Егоров П.М. (2015) Отношение рабочих промышленных предприятий Республики Саха (Якутия) к труду в условиях промышленного освоения // Приоритетные научные направления: от теории к практике. № 17. С. 73-77.

Игнатьева В.Б. (1999) Республика Саха (Якутия): Ретроспектива этнополитической истории. Новосибирск: Наука.

Концепция демографической политики Дальнего Востока на период до 2025 года (2017). Утверждена распоряжением Правительства Российской Федерации от 20 июня 2017 г. N 1298-p // https://www.garant.ru/products/ipo/prime/doc/71605978/

Малахов В.С. (2007) Понаехали тут... Очерки о национализме, расизме и культурном плюрализме. М.: Новое литературное обозрение.

Малахов В.С., Симон М.Е. (2017) Миграционная политика в условиях экономических турбулентностей: опыт Европейского союза и перспективы России (Migration Policy in the Conditions of Economic Turbulence: The Experience of the European Union and the Prospects of Russia) // https://ssrn.com/abstract=2980789

Международная миграция (2017) // Федеральная служба государственной статистики по Республике Саха (Якутия) // http://sakha.gks.ru/wps/wcm/connect/rosstat_ts/sakha/ resources/d3b11480450e024c9b17bfde4cdebdf4/d17_052017.doc

Межэтническая напряженность в меняющемся социальном контексте: результаты исследования (2017). М.: ФНИСЦ РАН.

Мостахова Т.С. (2016) Социально-демографические проблемы в Арктических районах Республики Саха (Якутия). Якутск: Сайдам.

Осипова О.В. (2016) Идентичности населения Якутии в контексте национальной политики Российской Федерации // Охлопков В.Е. (ред.) Этносоциологические исследования в Республике Саха Якутия. Сборник научных статей. Якутск: Институт гуманитарных исследований и проблем малочисленных народов Севера СО РАН. С. 73-91.

Прохода В.А. (2018) Отношение к мигрантам и уровень образования жителей европейских стран // Грунт Е.В., Меренков А.В., Антонова Н.Л. (ред.) Культура, личность, общество в современном мире: методология, опыт эмпирического исследования. Екатеринбург: УрФУ. С. 326-337.

Стендинг Г. (2014) Прекариат: новый опасный класс. М.: Маргинем Пресс.

Схема комплексного развития производительных сил, транспорта и энергетики Якутии до 2020 года (2006) // https://www.sakha.gov.ru/uploads/ckfinder/userfiles/files/Схема-2020.pdf

Тихонова Н.Е. (2014) Социальная структура России: теории и реальность. М.: Новый хронограф, Институт социологии РАН.

Тощенко Ж.Т. (2015) Прекариат - новый социальный класс // Социологические исследования. № 6. С. 3-13.

Тощенко Ж.Т. (2018) Прекариат: от протокласса к новому классу. М.: Наука.

Черныш М.Ф. (2016) Социокультурные и социоструктурные факторы межэтнической напряженности в регионах Российской Федерации: результаты исследования. Информационно-аналитический бюллетень. М.: Институт социологии РАН // http://www.isras.ru/files/File/publ/inab_2016_2(1).pdf

Шкаратан О.И. (2008) Воспроизводство социально-экономического неравенства в постсоветской России: динамика уровня жизни и положение социальных низов // Мир России. № 4. С. 60-89.

Шкаратан О.И., Карачаровский В.В., Гасюкова Е.Н. (2015) Прекариат теория и эмпирический анализ (на материалах опросов в России, 1994-2013) // Социологические исследования. № 12. С. 99-110.

Ford R. (2017) Three Things I Have Learned about Immigration Attitudes // Attitudes towards Immigration in Europe: Myths and Realities, pp. 10-12// https://www.europeansocialsurvey. org/docs/findings/IE_Handout FINAL.pdf

Rustenbach E. (2010) Sources of Negative Attitudes toward Immigrants in Europe: A MultiLevel Analysis // The International Migration Review, vol. 44, no 1, pp. 53-77.

Waisman G., Larsen B. (2016) Income, Amenities and Negative Attitudes // Journal of Migration, vol. 5, no 8, pp. 1-32 // https://izajodm.springeropen.com/articles/10.1186/s40176-016-0056-0 


\title{
The Impact of Socio-economic Status on Attitudes towards Migrants in the North-East of Russia
}

\section{O. VASIL'EVA*}

\begin{abstract}
*Olga Vasil'eva - PhD in Politics, Researcher, Institute for Humanities Research and Indigenous Studies of the North, Siberian Branch of Russian Academy of Sciences. Address: 1, Petrovskogo St., Yakutsk, 677027, Russian Federation. E-mail: olgaosipovaigi@gmail. com
\end{abstract}

Citation: Vasil'eva O. (2019) The Impact of Socio-economic Status on Attitudes towards Migrants in the North-East of Russia. Mir Rossii, vol. 28, no 4, pp. 152-171 (in Russian). DOI: $10.17323 / 1811-038 X-2019-28-4-152-171$

\begin{abstract}
Modern Russia faces several demographic challenges, among them population decline in the eastern regions of the country. Immigration is considered a solution to this problem. This raises the issue of the integration of migrants. This article looks at the socioeconomic context of anti-immigrant attitudes, specifically how socio-economic status affects attitudes towards migrants. The study is based on a survey conducted in three locations - Yakutsk, Nizhny Bestyakh and Neryungri in the Republic of Sakha - in 2016 and 2017. The sample is a quota sample of 654 respondents representing the population of the three locations by gender and age. While the findings generally point to favorable attitudes towards migrants in the Republic of Sakha, the study reveals a remarkable connection between self-assessed financial situation, education and age, on one hand, and attitudes towards migrants and perceptions of inter-ethnic relations, on the other. In addition, the current discourse, which emphasizes the ethnic coloring of migration and which also appears to be a significant factor in the formation of inter-ethnic tensions, seems to particularly affect the more socio-economically disadvantaged. I argue that this has potentially serious ramifications for the long-term assessment of the situation with inter-ethnic relations in the region, especially in the context of the Russian Concept of Demographic Policy.
\end{abstract}

Key words: migrants, integration of migrants, host society, social structure, social stratification, socio-economic status, anti-migrant attitudes, ethnic groups, Yakutia, interethnic relations, North-East Russia

\section{References}

Balibar E., Vallerstein I. (2004) Rasa, natsiya, klass. Dvusmyslennye identichnosti [Race, Nation, Class: Ambiguous Identities], Moscow: Logos. 
Chernysh M.F. (ed.) (2016) Sotsiokul'turnye i sotsiostrukturnye faktory mezhehtnicheskoj napryazhennosti $v$ regionakh Rossijskoj Federatsii: rezul'taty issledovaniya [Sociocultural and Socio-structural Factors of Interethnic Tensions in the Regions of the Russian Federation: Findings], Moscow: Institut sotsiologii RAN.

Demograficheskie vyzovy Rossii [Demographic Challenges of Russia] (2017). Center for Strategic Research. Available at: https://www.csr.ru/wp-content/uploads/2017/11/ReportDemography-web.pdf, accessed 31.08.2019.

Drobizheva L.M. (2012) Resurs mezhetnicheskogo soglasiya i balans neterpimosti v sovremennom rossijskom obshchestve [The Resource of Inter-Ethnic Tolerance and the Balance of Intolerance in Contemporary Russian Society]. Mir Rossii, no 4, pp. 91-110.

Drobizheva L.M. (2013) Ischezaet li etnichnost' v gorodskoj srede? Nekotorye otvety na zagadki bol'shogo goroda [Does Ethnicity Still Matter in the Urban Environment? Some Answers to the Mysteries of the Big City]. Izvestiya vysshikh uchebnykh zavedenij. Privolzhskij region. Obshchestvennye nauki, no 3(27), pp. 73-83.

Egorov P.M. (2015) Otnoshenie rabochikh promyshlennykh predpriyatij Respubliki Sakha Yakutiya $\mathrm{k}$ trudu $\mathrm{v}$ usloviyakh promyshlennogo osvoeniya [The Attitudes of Industrial Workers of the Republic of Sakha (Yakutia) to Work in Conditions of Industrial Development]. Priority Scientific Directions: from Theory to Practice, no 17, pp. 73-77.

Ford R. (2017) Three Things I Have Learned about Immigration Attitudes. Attitudes towards Immigration in Europe: Myths and Realities, pp. 10-12. Available at: https://www. europeansocialsurvey.org/docs/findings/IE Handout FINAL.pdf, accessed 31.08.2019.

Galkina M. (2014) «My predlagaem ne ogranichivat'sya Kitaem» ["We Suggest not to Be Limited to China"]. EastRussia.ru, June 17, 2014. Available at: https://www.eastrussia.ru/material/ my_predlagaem_ne_ogranichivatsya_kitaem/, accessed 31.08.2019.

Ignateva V.B. (1999) Respublika Sakha Yākutiya: Retrospektiva etnopoliticheskoj istorii [Sakha Republic (Yakutia): Retrospective of Ethnopolitical History], Novosibirsk: Nauka.

Kontseptsiya demograficheskoj politiki Dal'nego Vostoka na period do 2025 goda [The Concept of the Demographic Policy of the Far East until 2025] (2017). Available at: https://www.garant.ru/products/ipo/prime/doc/71605978/, accessed 31.08.2019.

Malakhov V.S. (2007) Ponaekhali tut... ocherki o natsionalizme, rasizme i kul'turnom plyuralizme [They Are Here: Essays on Nationalism, Racism and Cultural Pluralism], Moscow: Novoe literaturnoe obozrenie.

Malakhov V.S., Simon M.E. (2017) Migration Policy in the Conditions of Economic Turbulence: The Experience of the European Union and the Prospects of Russia. Available at: https://ssrn.com/abstract=2980789, accessed 31.08.2019.

Mezhdunarodnaya migratsiya [International Migration] (2017). Federal State Statistics Service for the Republic of Sakha (Yakutia). Available at: http://sakha.gks.ru/wps/wcm/connect/ rosstat_ts/sakha/resources/d3b11480450e024c9b17bfde4cdebdf4/d17_052017.doc, accessed 31.08.2019.

Mezhetnicheskaya napryazhennost'v menyayushchemsya sotsial'nom kontekste [Ethnic Tension in a Changing Social Context] (2017), Moscow: FCTAS RAS.

Mostakhova T.S. (2016) Sotsial'no-demograficheskie problemy v Arkticheskikh rajonakh Respubliki Sakha (Yakutiya) [Socio-demographic Problems in the Arctic Regions of the Republic of Sakha (Yakutia)], Yakutsk: Sajdam.

Osipova O.V. (2016) Identichnosti naseleniya Yakutii v kontekste natsional'noj politiki Rossijskoj Federatsii [The Identities of the Population of Yakutia in the Context of the National Policy of the Russian Federation]. Etnosotsiologicheskie issledovaniya v Respublike Sakha Yakutiya. Sbornik nauchnykh statej [Ethnosociological Studies in the Republic of Sakha Yakutia. Collection of scientific articles] (ed. Okhlopkov V.E.), Yakutsk.: Institut gumanitarnykh issledovanij i problem malochislennykh narodov Severa SO RAN, pp. 73-91.

Prokhoda V.A. (2018) Otnoshenie k migrantam i uroven' obrazovaniya zhitelej evropejskikh stran [Attitude towards Migrants and the Level of Education of Residents of European Countries]. Kul 'tura, lichnost', obshchestvo v sovremennom mire: metodologiya, opyt empiricheskogo issledovaniya [Culture, Personality, Society in the Modern World: Methodology, Experience of Empirical Research] (eds. Ground E.V., Merenkov A.V., Antonova N.L.), Ekaterinburg: UrFU, pp. 326-337. 
Rustenbach E. (2010) Sources of Negative Attitudes toward Immigrants in Europe: A MultiLevel Analysis. The International Migration Review, vol. 44, no 1, pp. 53-77.

Shkaratan O.I. (2008) Vosproizvodstvo sotsial'no-ekonomicheskogo neravenstva v postsovetskoj Rossii: dinamika urovnya zhizni i polozhenie sotsial'nykh nizov [Reproduction of Socioeconomic Inequality in post-Soviet Russia: the Dynamics of Living Standards and the Position of the Lower Social Classes]. Mir Rossii, no 4, pp. 60-89.

Shkaratan O.I., Karacharovskij V.V., Gasyukova E.N. (2015) Prekariat: teoriya i empiricheskij analiz (na materialakh oprosov v Rossii, 1994-2013) [Precariat: Theory and Empirical Analysis (based on surveys in Russia, 1994-2013)]. Sotsiologicheskie issledovaniya, no 12 , pp. $99-110$.

Skhema kompleksnogo razvitiya proizvoditel'nykh sil, transporta $i$ energetiki Yakutii do 2020 goda [The Scheme of Complex Development of Productive Forces, Transport and Power Industry of Yakutia till 2020] (2006). Available at: https://www.sakha.gov.ru/uploads/ckfinder/userfiles/files/Схема-2020.pdf, accessed 31.08.2019.

Standing G. (2014) Prekariat: novyj opasnyj klass [The Precariat: The New Dangerous Class], Moscow: Marginem Press.

Tikhonova N.E. (2014) Sotsial'naya struktura Rossii: teorii i realnost' [Social Structure of Russia: Theories and Reality], Moscow: Novyj khronograf, Institut sotsiologii RAN.

Toshchenko Zh.T. (2015) Prekariat - novyj sotsial'nyj klass [The Precariat - the New Social Class]. Sotsiologicheskie issledovaniya, no 6, pp. 3-13.

Toshchenko Zh.T. (2018) Prekariat: ot protoklassa k novomu klassu [Precariat: from Protoclass to New Class], Moscow: Nauka.

Vishnevskij A.G., Andreev E.M., Shcherbakova E.M. (2017) Demograficheskie vyzovy Rossii. Chast pervaya - naselenie i prostranstvo [Demographic Challenges of Russia. Part one - Population and Space]. DemoscopeWeekly, no 749-750. Available at: http://demoscope.ru/weekly/2017/0749/tema01.php, accessed 31.08.2019.

Waisman G., Larsen B. (2016) Income, Amenities and Negative Attitudes. Journal of Migration, vol. 5, no 8, pp. 1-32. Available at: https://izajodm.springeropen.com/articles/10.1186/s40176-016-0056-0, accessed 31.08.2019. 